\title{
$0295 x$
}

EML- -428

DE84 014122

RADEX: AN ACTIVE MONITOR FOR CONTINUOUS MEASUREMENT OF ${ }^{22}$ Rn FLUX IN SOIL

By

Sidney Watnick

Norman Latner

Robert T. Graveson

May 1984

Environmental Measurements Laboratory

New York, New York

Technical Information Center

Office of Scientific and Technical Information

United States Department of Energy 


\section{DISCLAIMER}

This report was prepared as an account of work sponsored by an agency of the United States Government. Neither the United States Government nor any agency Thereof, nor any of their employees, makes any warranty, express or implied, or assumes any legal liability or responsibility for the accuracy, completeness, or usefulness of any information, apparatus, product, or process disclosed, or represents that its use would not infringe privately owned rights. Reference herein to any specific commercial product, process, or service by trade name, trademark, manufacturer, or otherwise does not necessarily constitute or imply its endorsement, recommendation, or favoring by the United States Government or any agency thereof. The views and opinions of authors expressed herein do not necessarily state or reflect those of the United States Government or any agency thereof. 


\section{DISCLAIMER}

Portions of this document may be illegible in electronic image products. Images are produced from the best available original document. 


\title{
DISCLAIMER
}

\begin{abstract}
This report was prepared as an account of work sponsored by an agency of the United States Government. Neither the United States Government nor any agency thereof, nor any of their employees, makes any warranty, express or implied, or assumes any legal liability or responsibility for the accuracy, completeness, or usefulness of any information, apparatus, product, or process disclosed, or represents that its use would not infringe privately owned rights. Reference herein to any specific commercial product, process, or service by trade name, trademark, manufacturer, or otherwise does not necessarily constitute or imply its endorsement, recommendation, or favoring by the United States Government or any agcncy thereof. The views and opinions of authors expressed herein do not necessarily state or reflect those of the United States Government or any agency thereof.
\end{abstract}

This report has been reproduced directly from the best available copy.

Available from the National Technical Information Service, U. S. Department of Commerce, Springfield, Virginia 22161.

Price: Printed Copy A02

Microfiche A01

Codes are used for pricing all publications. The code is determined by the number of pages in the publication. Information pertaining to the pricing codes can be found in the current issues of the following publications, which are generally available in most libraries: Energy Research Abstracts (ERA); Government Reports Announcements and Index (GRA and I); Scientific and Technical Abstract Reports (STAR); and publication NTIS-PR-360 available from NTIS at the above address. 
EML-428

(DE84014122)

Distribution Category UC-11

\title{
RADEX: AN ACTIVE MONITOR FOR CONTINUOUS MEASUREMENT OF ${ }^{22}$ Rn FLUX IN SOIL
}

\author{
By \\ Sidney Watnick \\ Norman Latner \\ Robert T. Graveson
}

May 1984

\author{
Environmental Measurements Laboratory \\ U. S. Department of Energy \\ New York, New York
}




\section{ABSTRACT}

A radon exhalation monitor, RADEX, was developed at the Environmental Measurements Laboratory. RADEX is an active radon monitor that continuously samples radon gas emanating from the soil. A hemispherical accumulator is placed on the soil and radon $g$ as is drawn into the RADEX counter at a low, controlled flow rate. As $222 \mathrm{Rn}$ decays, the resulting radon daughters are focused by an electrostatic field, deposited directly onto a semiconductor detector, and counted. RADEX's ability to detect rapid changes in radon exhalation is made possible by analyzing RaA alphas with fast decay times. The pulses produced by the radon daughters are integrated hnirly and are recorded. This system can operale unattended for 1 week, at which time a desiccant column must be changed. Thus, RADEX allows one to observe and to record continously the radon flux from the soil. 


\section{INTRODUCTION}

To accurately measure radon flux from the earth requires a system that will not disturb the natural terrain. Unfortunately, at present no system is available that totally meets this requirement. To date, there are two approaches available. The first is a loosely-coupled arrangement, i.e., when the collecting device is lightly sitting on the soil, which has the advantage of minimal disturbance to the natural terrain. However, it suffers from serious dilution problems when the ambient air mixes with the radon gas emanating from the soil. This results in a lower and unpredictably variable measurement of the actual radon flux being released from the ground. The second is a tightly coupled arrangement, which involves sampling on or slightly into the soil and, as such, affects the natural interaction that occurs at the soil/air interface. Isolated from the atmosphere and acting like a blanket, the sampling area becomes immune to normal environmental phenomena such as wind, rain, snow and temperature variations. Thus, because the normal interaction between the emanated radon and the surrounding air is inhibited, the measurement is often biased towards the higher values. However, since the tightly-coupled measurements are immune to the variability encountered with the loosly-coupled samp1ing, the former determinations yield a more accurate assessment of the actual exhalation rate of the radon gas.

We have used the later method to develop a continuous monitoring instrument, the RADEX, for determining radon flux. The RADEX monitoring system is discussed in detail in this report.

\section{INSTRUMENTATION}

Sampling methods presently nsed for measuring radon exhalation from the earth are generally based on passive detection devices, such as: track etch film, charcoal canisters, and accumulators (F1eischer, 1980; Countess, 1976; Kraner et al., 1964). For the design of RADEX, an active accumulator is nsed for measuring the radon flux. Figure 1 shows the hermispherical accumalator, which has a diameter of 23 ciil and a volume of $7 \mathrm{~L}$. The accumulator is placed onto a rim that has been anchored into the ground to a depth of at least 1 to $2 \mathrm{~cm}$. Attached to the accumulator is a length of Tygon tubing through which air and the radon $g$ as is removed at a constant flow rate. The combination of a cold trap ( $1.8 \mathrm{~L}$ in volume) and a filter tabe (Balston) will remove most of the moisture from the sample. At this point in the $100 p$, the pump is located. A continuous and constant flow rate of $200 \mathrm{~mL} \cdot \mathrm{min}^{-1}$ is regulated by a pressure-switch and associated circuitry. Figure 2 shows the pump with its control circuit which is described in detail in EML-389 (Latner et a1.., 1981). After the pump, a desiccant column removes the remaining moisture from the sample before it enters the counting chamber. In addition, $7.6 \mathrm{~cm}$ diameter glass fiber filter is used to remove the radon daghters and, thus, only radon enters the counting chamber. 
The counting chamber (shown in Figure 3 ) is cylindrical in shape, $24.5 \mathrm{~cm}$ in diameter, $21.3 \mathrm{~cm}$ in height and has a volume of $10 \mathrm{~L}$. The al uminum counting chamber is lined with Teflon, which has aluminum foil attached to the inner surface. The foil is insulated from the cylinder housing, allowing a high potential to be applied to the foil without electrical breakdown occurring. A positive $3500 \mathrm{~V}$ is applied to the foil, establishing a static electric field. The electric field acts to focus and direct the newly formed radon daughters towards the detector (Wrenn et a1., 1975; Negro and Watnick, 1978). The ionized molecules then deposit directly onto the active area of the detector. A Surface Barrier Solid State Detector, $300 \mathrm{~cm}^{2}$ in area and ring mounted, is used in the RADEX monitor. The detector is mounted in a Teflon holder, which insulates it from the chambers electric field potentia1. An ' 'O' ring is used to hermetically seal this assembly to the counting chamber and, thus, insure proper sample flow from inpt to output ports. The ring mounted detector, by virtue of its minimum mass housing, maximizes the ratio of active detector area to inactive area, thus, offering the greatest possible sensitivity.

Figure 4 shows the circuitry, which can be divided into four main sec tinns. Thosc are: the air flow system, the power supplies, the chargesensitive preamplifier, and the window counter/comparator circuits.

The signal developed by the surface barrier detector is coupled to a compact charge-sensitive preamplifier designed around a 1 ow power, triple operational amplifier chip (L144). This circuitry has been described in detail previously (Watnick and Latner, 1982). An emitter follower acts as a buffer between the preamplifier and an associated multichannel analyzer that processes the analog signals. Typical waveforms for RaA (218Po, $6 \mathrm{MeV}$ ) and RaC' (214Po $7.8 \mathrm{MeV}$ ) alpha pulses are shown in Figure 5 .

The preamplifief output is also routed $l_{0}$ a window counter/comparator circuit. This unique circuit design uses a very efficient arrangement of the four sections of a single chip, low power, quad comparator (L166). The input stage utilizes two of the comparators to form upper- and lower-level discriminators. A RaA (218Po) alpha signal will cause the normally 'off' output of the lower-1evel discriminator to turn on. When this occurs, a ramp voltage is generated at its output at the junction of capacitor (C) and diode (D). For a typical $80 \mu s e c$ wide input pulse, the ramp roltage will reach a peak amplitude of $1.7 \mathrm{~V}$ before the pulse is terminated. At 1 evels above $1 \mathrm{~V}$, the lower-level comparator (L.C.) goes on, and delivers an output pulse which represents an RaA (218Po) event. An RaC' (214Po) alpha signal activates both the lower and upper-1evel discriminators. The upper-level discriminator then places the diode near ground potentinl. This effectively prevents the ramp from rising (see Figure 5), and the lower-level discriminator from giving an ontput. The upper-level comparator (U.C.), however, because of its biasing arrangement, now turns on as its input drops to zero. The pulse output from this upper-1evel comparator represents an $\mathrm{RaC}^{\prime}$ (214Po) event. Thus, in addition to the analog signala routed to the multichannel analyzer, digital signals are available for recording RaA (218Po) and RaC' (214Po) events on automatic data logging equipment suoh as EML's CLEVER or SMART COUNTERS (Po1ito and Negro, 1979). 
As in the analog circuitry, the digital outputs are buffered with emitter followers using three of the five transistor arrays packaged in a single integrated circuit (CA3046).

Power for the preamplifier and window conter circuits is supplied by a 9. V battery to a group of regulators whose total current drain is $1 \mathrm{~mA}$, allowing the circuits to operate continuously for 2 weeks. The bias supply for the detector consists of two-22 $1 / 2 \mathrm{~V}$ miniature batteries that will operate for as long as their shelf life. To allow extended operation, where a.c. power is available, the $9 \mathrm{~V}$ battery can be replaced by an external porer supp1y.

Physically, the circuits are mounted on a printed circuit board packaged in a plastic box whose dimensions are $4 \times 10 \times 3 \mathrm{~cm}$. Both the circuit and bias batteries are housed within this enclosure.

The high voltage porer supply used to generate the static field is a d.c.to - d.c. converter type. It supplies an output of $3500 \mathrm{~V}$ for an input of $5 \mathrm{~V}$ with a $10 \mathrm{~mA}$ drain (see Pigure 6). Transformer (T1) with transistor (TR1) form a blocking oscillator that allows a voltage stepup to about $900 \mathrm{~V}$. A voltage quadruplier is then used to increase the ontput to $3500 \mathrm{~V}$ d.c. This technique is quite effective in this application because of the insignificant drain on the high voltage power supply. A portion of the ontput is sampled and appears at one input of IC1, a 1 or current comparator whose reference input is tied to a stable, temperature-compensated v01tage. IC2, a CD4007 dual complementary pair, buffers and inverts the comparator output. This signal then controls the base drive signal for TR1, the blooking oscillator, supplying the necessary correction to hold the output constant.

Figure 7 shows the 10 voltage power supply, which uses micropower d.c. regulators and voltage converters. The input voltage from the nominal $9 v$ battery is applied to IC1 and IC2. IC1 and IC2 then supply a +5 V output as long as the input battery voltage remains above $5.2 \mathrm{~V}$. In order to achieve a high degree of isolation, one of the $+5 V$ regulator circuits is used exclusively to power the high-voltage circuit. The remaining +5 $V$ regulator powers two monolithic voltage converters, IC3 and IC4. IC3 functions as a voltage donbler, producing tho positive $9 v$ and, in addition, supplies a negative input for IC4. IC4, in turn generates the negative $9 \mathrm{~V} 1$ ine. Since the loading of these supplies remains relatively constant, the output voltages are quite stable.

\section{CALIBRATION}

Calibration of the RADEX monitor, a necessary step prior to initial use of the instrument, involves setting the window counter discriminator levels, as well as the energy integration regions on the associated multichannel analyzer. The calibration procedure requires that the monitor be place in an 
atmosphere of $222 R n$ activity maintained at a constant level. We chose 32 $\mathrm{pCi} / \mathrm{L}$. At the same time, information on system resolution, stability, and collection efficiency can be obtained. During calibration, a scope display of the preamplifier alpha pulses (Figure 5) shows $2.3 \mathrm{~V}$ for RaA (218Po) and $2.9 \mathrm{~V}$ for $\mathrm{RaC}^{\prime}(214 \mathrm{Po})$.

Discriminator levels can then be set to give appropriate logic outputs for digital counting. These pulses are also routed to the maltichannel analyzer, allowing a determination of the resolution of the RADEX monitor. The $6 \mathrm{MeV} \operatorname{RaA}$ (218Po) peak shows a resolution of $120 \mathrm{keV}$ FWHM (full width at half-maximum height). This level of resolution allows for ample separation between it and the $7.8 \mathrm{MeV} \mathrm{RaC}^{\prime}$ (214Po) peak, and includes a significant margin to compensate for minor signal drifts that may occur during extended counting periods.

A good approximation of the RADEX monitor's cullection efficiency for RaA (21*Po) and Rar. (214Po) alphas can be determined using the following equation (Negro and Watnick, 1978), which is valid for constant radon concentrations:

$$
\mathrm{C}_{\mathrm{Rn}}=\frac{\mathrm{X}}{\mathrm{Z}^{\prime}} \frac{0.45}{\mathrm{EV} \mathrm{Ff}}
$$

where

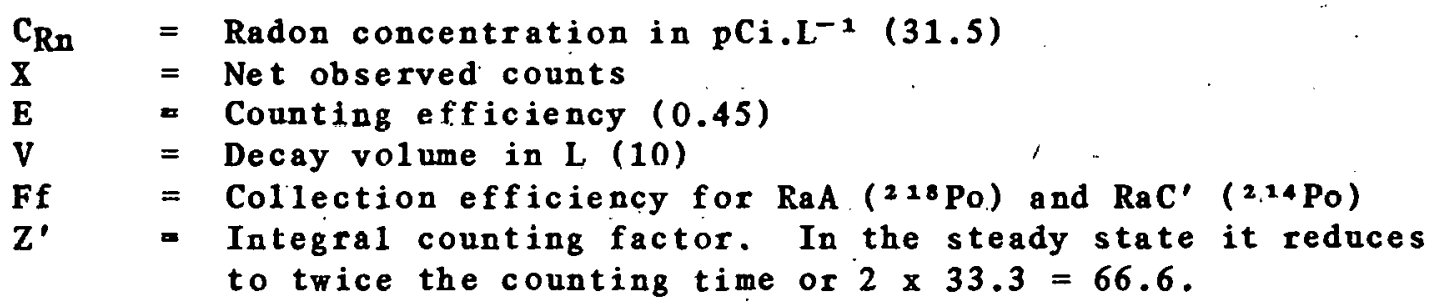

The observed counts were averaged for 16 counting periods of $33.3 \mathrm{~min}$ each.

The following results were obtained:

$$
31,5=\frac{9750.31}{66.6} \quad \frac{0.45}{0.45 \times 10 \times \mathrm{Ff}}
$$

$\operatorname{RaA}(218 \mathrm{Po})$ and RaC' (214Po) Ff $-46.5 \%$

$$
31.5=\frac{4651.75}{33.3} \quad \frac{0.45}{0.45 \times 10 \times \mathrm{Ff}}
$$




$$
\begin{aligned}
& \operatorname{RaA}(218 \mathrm{Po}) \quad F f=44.3 \% \\
& 31.5=\frac{5099.94}{33.3} \frac{0.45}{0.45 \times 10 \times \mathrm{Ff}} \\
& \mathrm{RaC}^{\prime}(214 \mathrm{Po}) \quad \mathrm{Ff}=48.6 \%
\end{aligned}
$$

Clearly, the collection efficiency of this instrument is high. The small losses can be attributed to the RaA (218Po) ions being deposited onto the dead area and the printed circuit material of the surface barrier detector (Negro and Watnick, 1978). Other losses may be caused by neutral or negatively charged ions that will not be deposited on the detector.

The sensitivity calibration of the RADEX monitor requires a comparison with an independent measurement method, such as the use of charcoal canisters. Pulverized, homogenously mixed soil that had been spiked with various amounts of $226 \mathrm{Ra}$ was put into containers. These containers were plastic lined wooden boxes with dimensions of $46 \mathrm{~cm}$ on each side by $28 \mathrm{~cm}$ high. The hemispherical sampling unit of the RADEX monitor, as well as two charcoal canisters, were placed upon the prepared soil and remained there for periods of time ranging from 24 to $72 \mathrm{hr}$. The charcoal canisters were then removed, analyzed in a gama scintillation counter, and a radon flux value was calculated. Because of the uniform nature of the spiked soil bed, the RADEX sampler was exposed to the same flux level's as the charcoal canisters. An accurate comparison can then be made by relating the observed count of the RADEX monitor to the radon flux determined with the charcoal canisters. For improved accuracy, the measurements were repeated many times at different concentrations, and the results averaged. A plot of RADEX cpm vs. radon flux (Figure 8) was made and served as the calibration curve of the RADEX monitor. The sensitivity derived from the calibration curve is $1.0 \mathrm{cpm}$ which is equal to $0.984 \mathrm{aCi} \cdot \mathrm{cm}^{-2} \cdot \mathrm{s}^{-1}$.

\section{FIELD TESTS}

After completing all laboratory tests and calibrations, the RADEX monitor underwent field testing at our remote station at Chester, New Jersey to uncover any problems that might be caused by the effects of temperature. humidity, and fluctualiuis in line voltage. For these tests, the sampling hemisphere was placed on the soil, while the remainder of the RADEX system was located in a nearby trailer (see Figures 9A and 9B). Tygon tubing was used for sample transport between ontside and inside. Fignre 10 shows a 10-day plot of hourly readings taken with the RADEX monitor at Chester, New Jersey. 
In order to verify the measurement accuracy of the RADEX monitor ander field conditions, sampling was performed for $6 \mathrm{hr}$ using an accumalator that operated on a set schedule. Samples from the accumulator were taken by an evacuated gas collecting cylinder after 15 and $45 \mathrm{~min}$, at which time the accumulator was removed from the soil for 15 min. This procedure was repeated four times. Over the same time periods, gas samples were also removed (again using an evacuated cylinder) from the sampling hemisphere of the RADEX monitor. Simultaneously, the RADEX monitor was in operation throughout these tests. Table 1 shows the results of these tests, comparing the RADEX monitor, the gas sample from the monitor and the accumalator. It should be noted that the sample reaching the RADEX detector and that which is drawn from the sample head are identical and lend themselves to a valid intercalibration of the response of the detector system. However, comparisons between these and the accumalator are less certain. The accumulator is obviously not sampling the same area as the RADEX, and may be exposed to different activity levels. In addition, the accumulator is a pasive device, while the RADEX is active. Thus, while the results of the accumulator measurements are included in Tablc 1 , [urther prperimonts are utecssary to estabiish lle relationship between these two sampling methods. With this aside, agreement is good except for those periods during or following a rainfall where the RADEX reads higher. This difference arises from the fact that the hemispheric sampler always remains on the ground and prevents the soil beneath it from getting wet, and the other sampling methods used do allow the soil to get wet. The diffusion rate of radon gas is different for wet and dry soil.

\section{CONCLUSION}

The RADEX monitor has been in continuous operation for a period of over 6 months, with tests made on a regular basis. It has shown itself to be a useful, accurate and reliable instrument that can be used to examine rapid changes of radon exhalation from the earth and to make continuous measurements over any repeated time periods.

As a cautionary note, it is possible that the measurements may be biased towards a higher value because of two factors. The first is the small negative pressure applied to the area being sampled. The second is the effect of the tested area boing oovered by the hemispherical sampler and, thus, being isolated from the normally occurring olimalic variations. Future plans have been formulated to further stady and improve the RADEX monitor. The effoct of air. flow rate on exhalation factor will be investigated. 


\section{ACKNOTLEDGMENTS}

We wonld like to acknowledge the help we received for this project and to express our personal thanks to Irwin Haske11, who assisted in running the experiments at Chester, and to Isabel Fisenne and Andreas George for analyzing the charcoal canisters and gas samples. 
Countess, R. J.

-222Rn F1ux Measurements With Charcoal Canisters'

Health Physics, 31, 455-456 (1976)

Fle ischer, R. L.

'Radon Flux From the Earth: Methods of Measurement by the Nuclear Track Technique'

J. Geophys. Res., 85, 7553-7556 (1980)

Kraner, H. W., Schroeder, G. L., and Evans, R. D.

'Heasurements of the Effects of Atmospheric Variables on Radon-222 F1ux and Soil-Gas Concentrations.

The Natural Radiation Environment, John A. S. Adams and Wayne M. Lowder

(Editors), Chicago: University of Chicago Press, pp, 191-215 (1964)

Latner, N., Watnick, S. and Graveson, R. T.

'Integrating Working Level Monitor, ËL Typo TF-11'

USDOE Report EML-389 (1981)

Negro, V. C. and Watnick, S.

'FUNGI: A Radon Measuring Instrument with Fast Response'

IEEE Trans. Nuc1. Sci., NS-25, 757-761 (1978)

Polito, M. D. and Negro, V. C.

'SMART-I and CLEVER COUNTER: Environmental Data Acquisition Systems'

IEEE Trans. Nuc1. Sci., NS-26, 765-769 (1979)

Watnick, S. and Latner, N.

'Mintature, Low Power Charge Sensitive Preamplifier'

USDOE Report EML-408 (1982)

Wrenn, McDona1d, E., Spitz, H. and Cohen, N.

'Design of a Continuous Digita1-Ontput Environmental Radon Monitor'

IEEE Trans. Nuc1. Sci.. NS-22, 6456-57 (1975) 
TABLE 1

CHESTER, NJ INTERCOMPARISON FLUX MEASUREMENTS $\left(\mathrm{aCi} \cdot \mathrm{cm}^{-2} \cdot \mathrm{s}^{1}\right)$

\begin{tabular}{|c|c|c|c|c|}
\hline Date & $\begin{array}{l}\text { Weather } \\
\text { Condition }\end{array}$ & $\begin{array}{l}\text { RADEX } \\
\text { Monit or }\end{array}$ & $\begin{array}{c}\text { Gas Sample } \\
\text { from } \\
\text { RADEX } \\
\text { Monit or }\end{array}$ & Accum 1 a tor \\
\hline $6 / 29 / 83$ & C1 e a r & $180.23 \pm 20.4$ & \pm 43 & N.D. \\
\hline $7 / 11 / 83$ & Clear & $65.58 \pm 4.04$ & \pm 7.9 & $67.6 \pm 16.1$ \\
\hline $7 / 13 / 83$ & Clear & $43.31 \pm 4.88$ & $53.6 \pm 13$ & N. D. \\
\hline $7 / 25 / 83$ & Rain & $99.9 \pm 1.03$ & $99.6 \pm 31.3$ & $75.24 \pm 48.63$ \\
\hline $7 / 27 / 83$ & Clear & $90.69 \pm 3.3$ & \pm 10.2 & $63.1 \pm 15.7$ \\
\hline $8 / 17 / 83$ & C1 eax & \pm 10.55 & $134.8 \pm 49.75$ & $149.2 \pm 60.2$ \\
\hline $8 / 31 / 83$ & Rain & \pm 11.23 & \pm 49 & \pm 52 \\
\hline
\end{tabular}

N.D. = samples lost in preparation. 


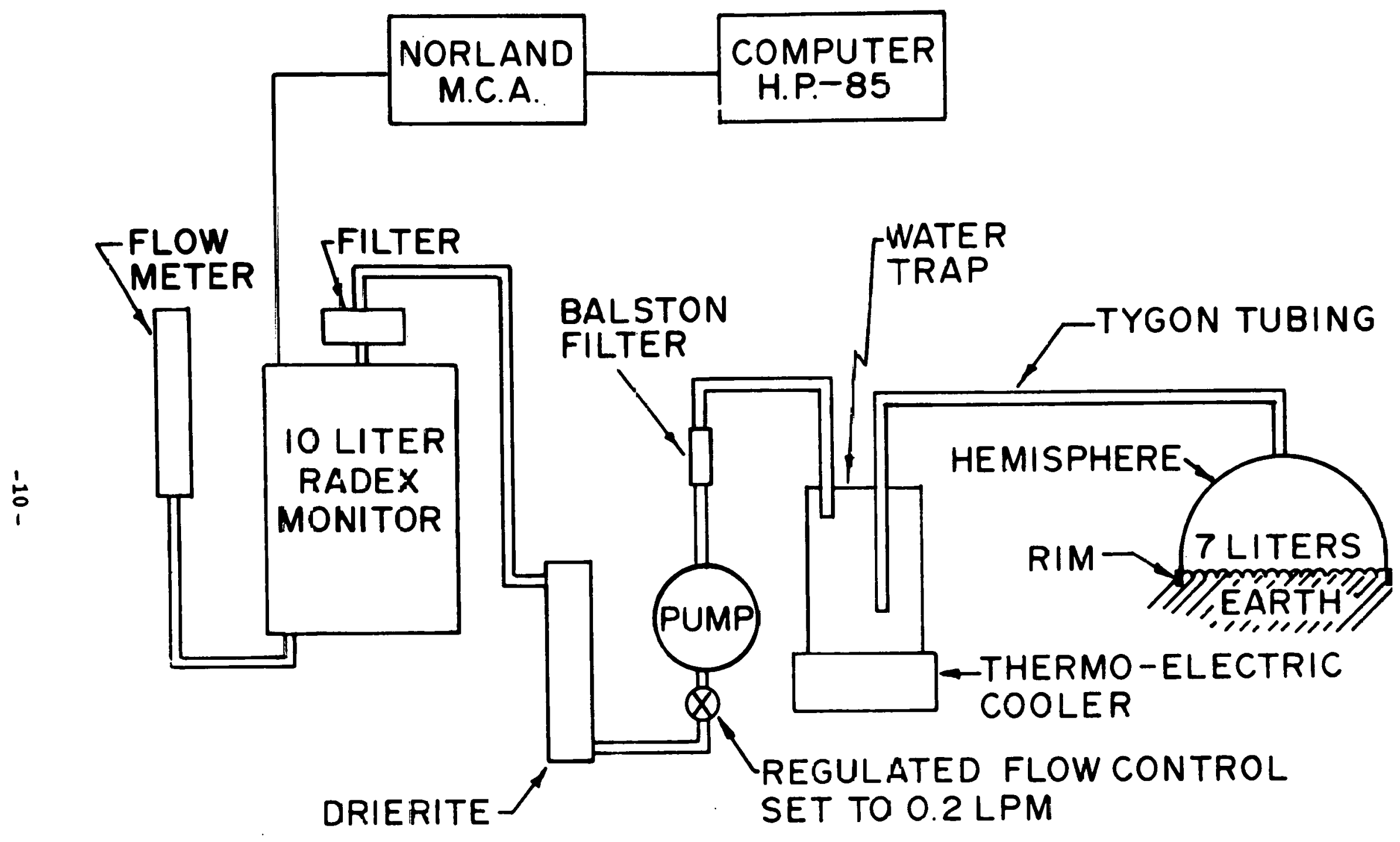

Figure 1. RADEX moritor. 


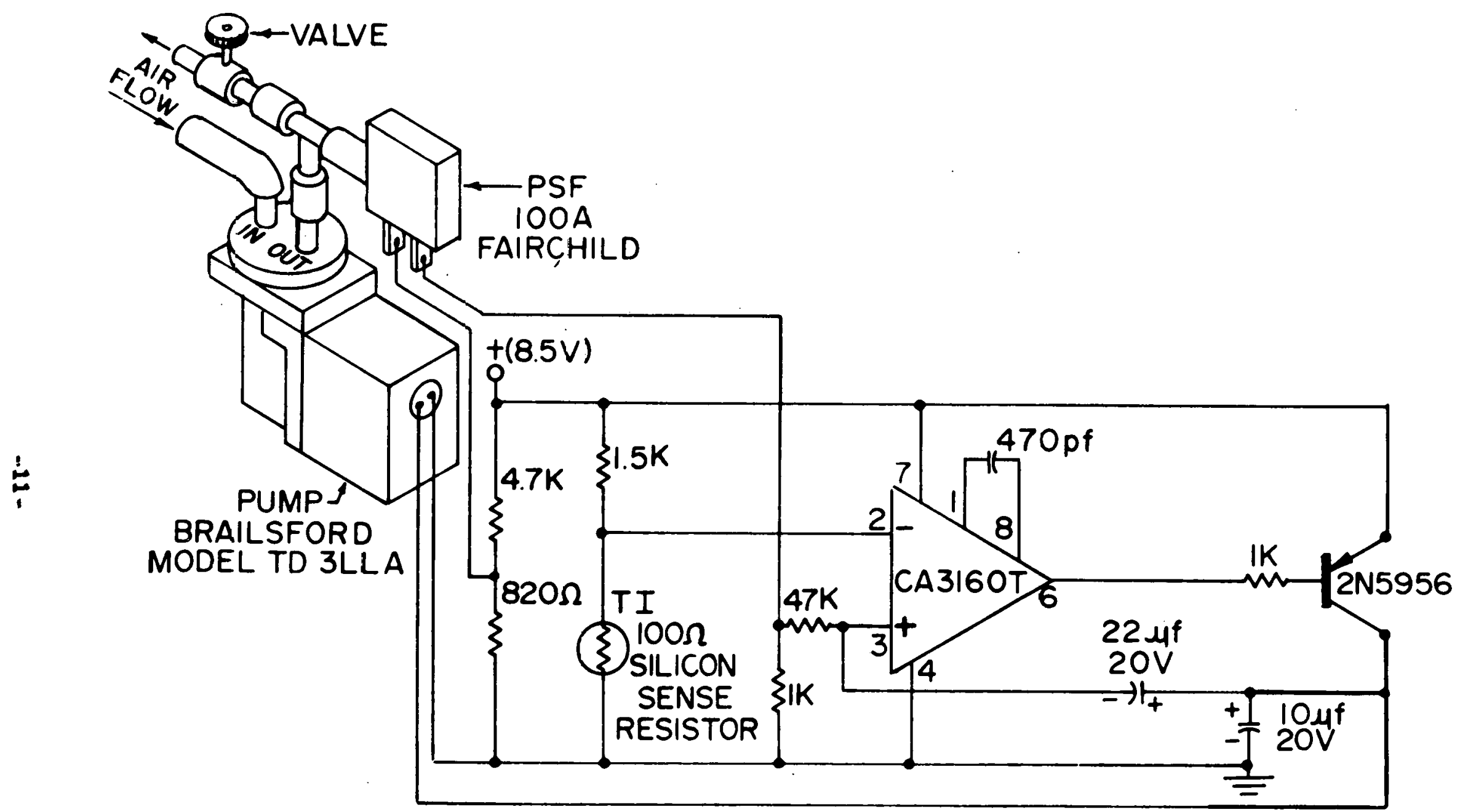

Figure 2. Constant flom pump system: 


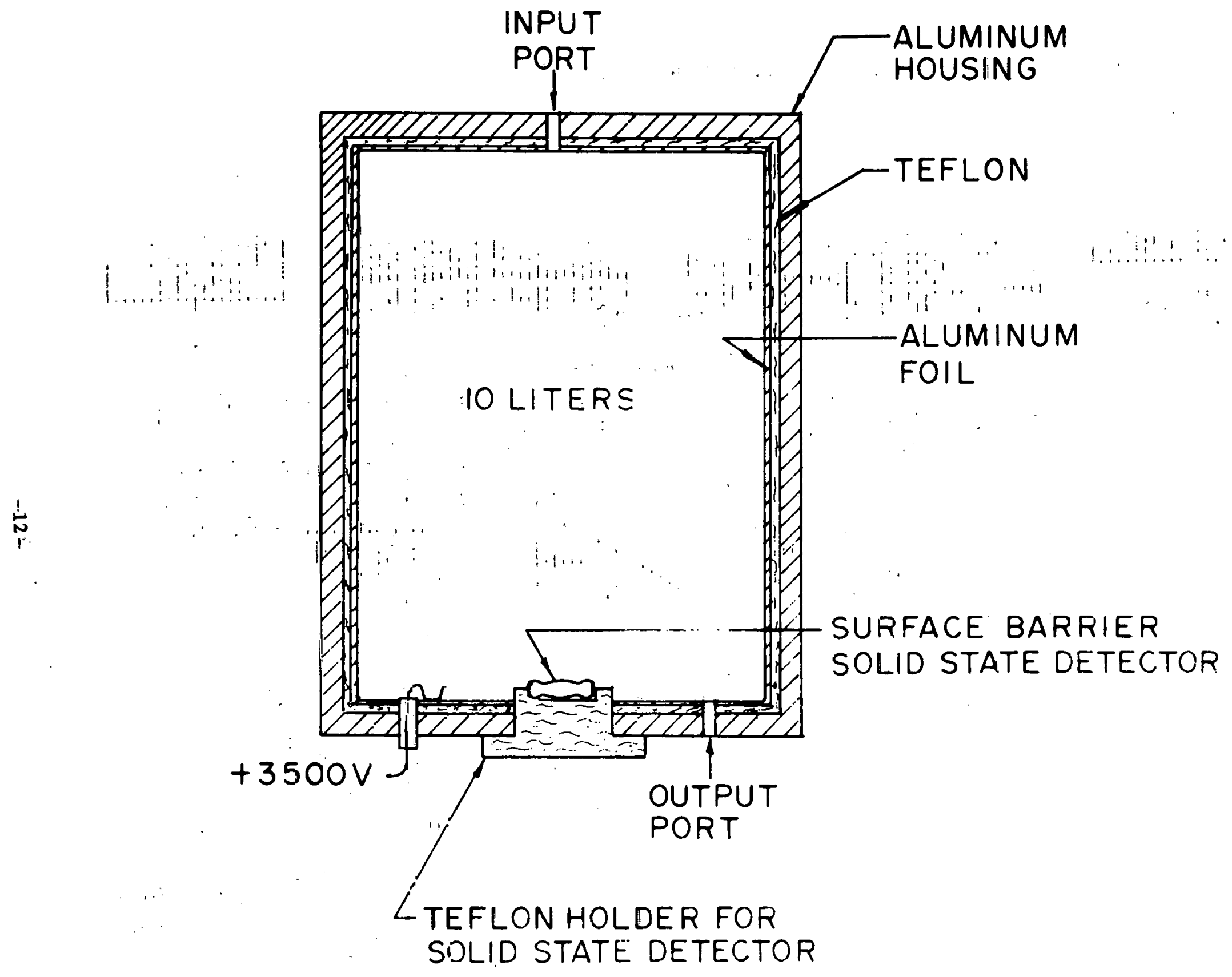

Figure 3. Detector chamber. 


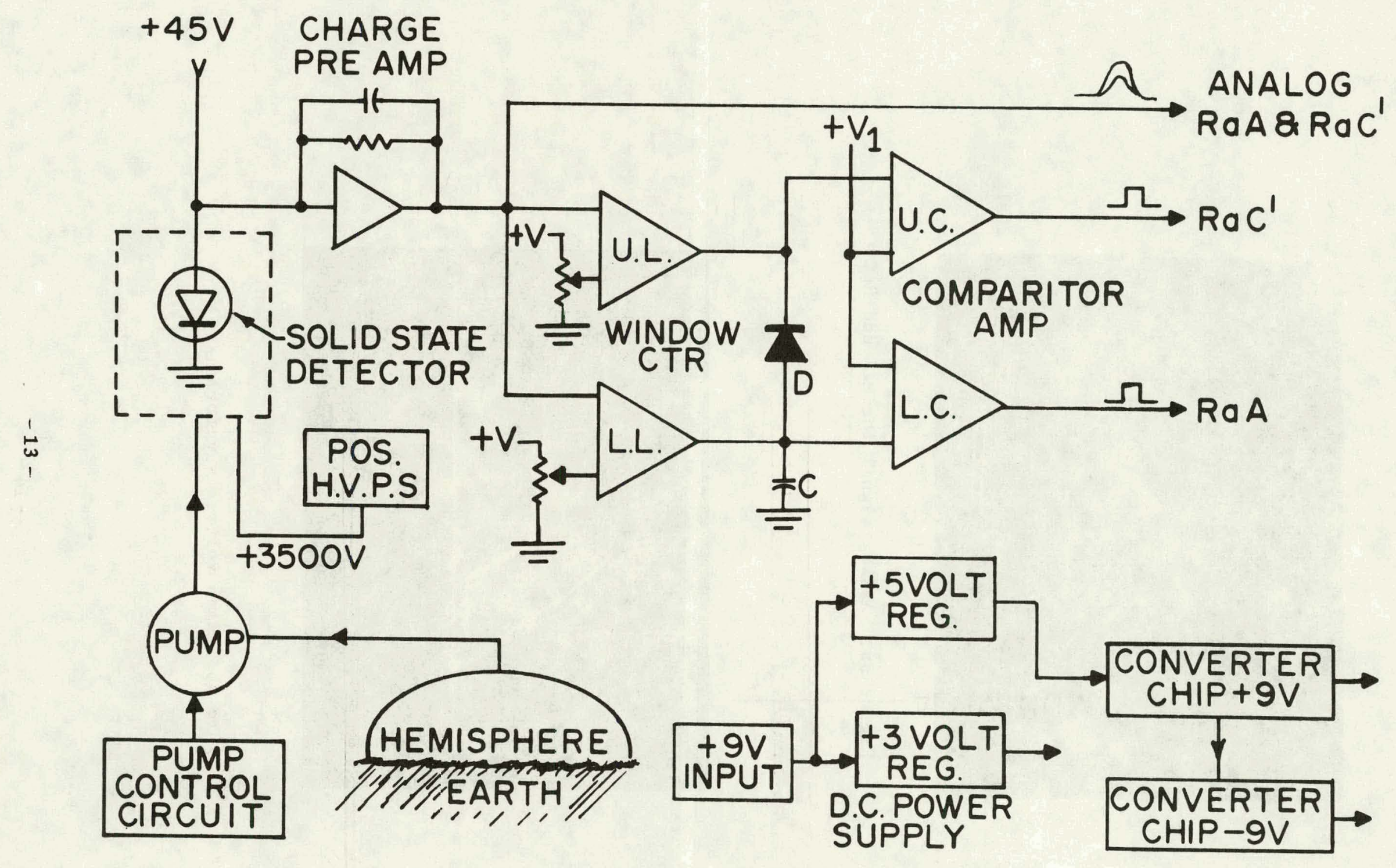

Figure 4. Circuit diagram. 


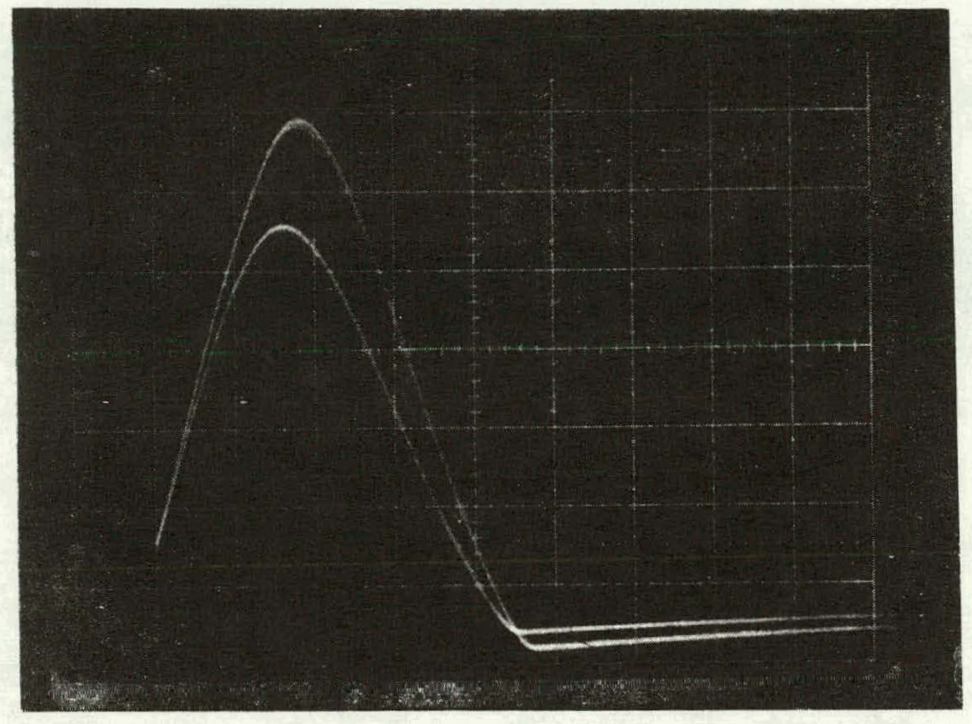

Figure 5a. Analog signal for RaA and RaC'.

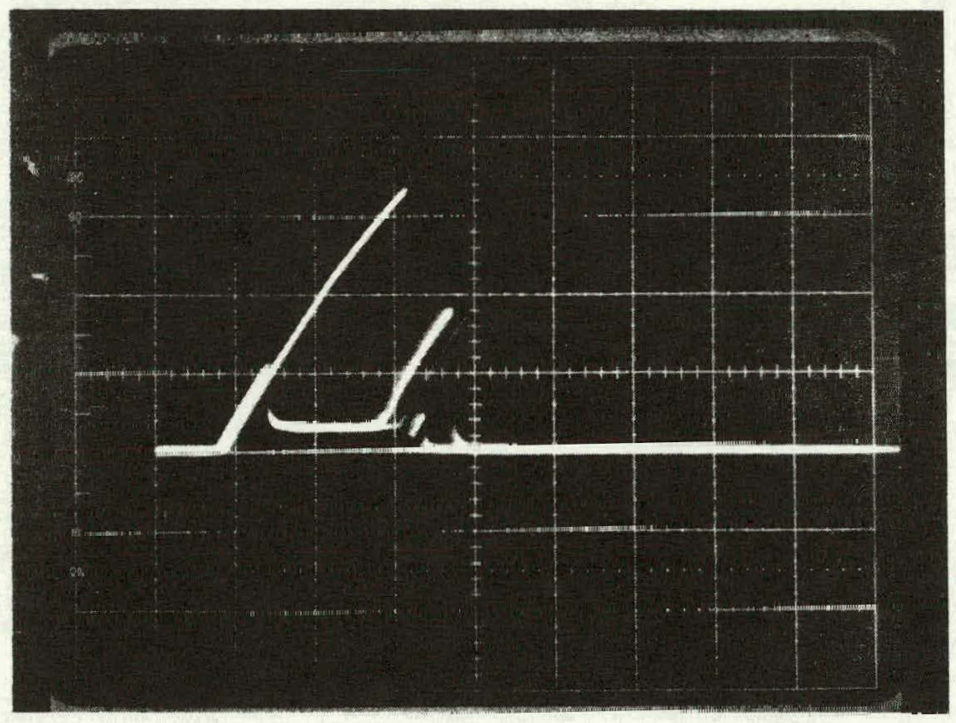

Figure 5b. Ramp voltage waveforms. 


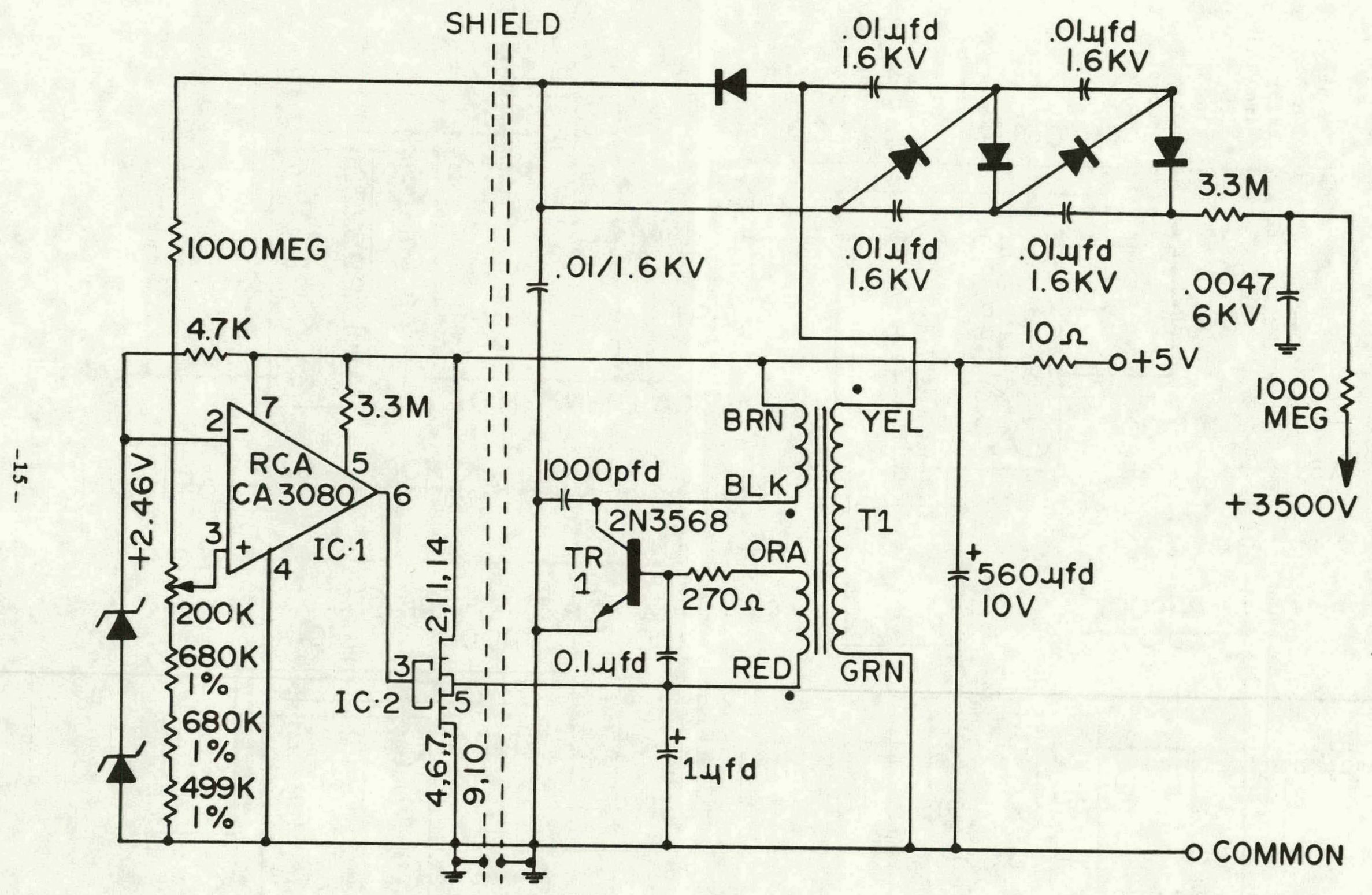

Figure 6. High voltage circuit diagram. 


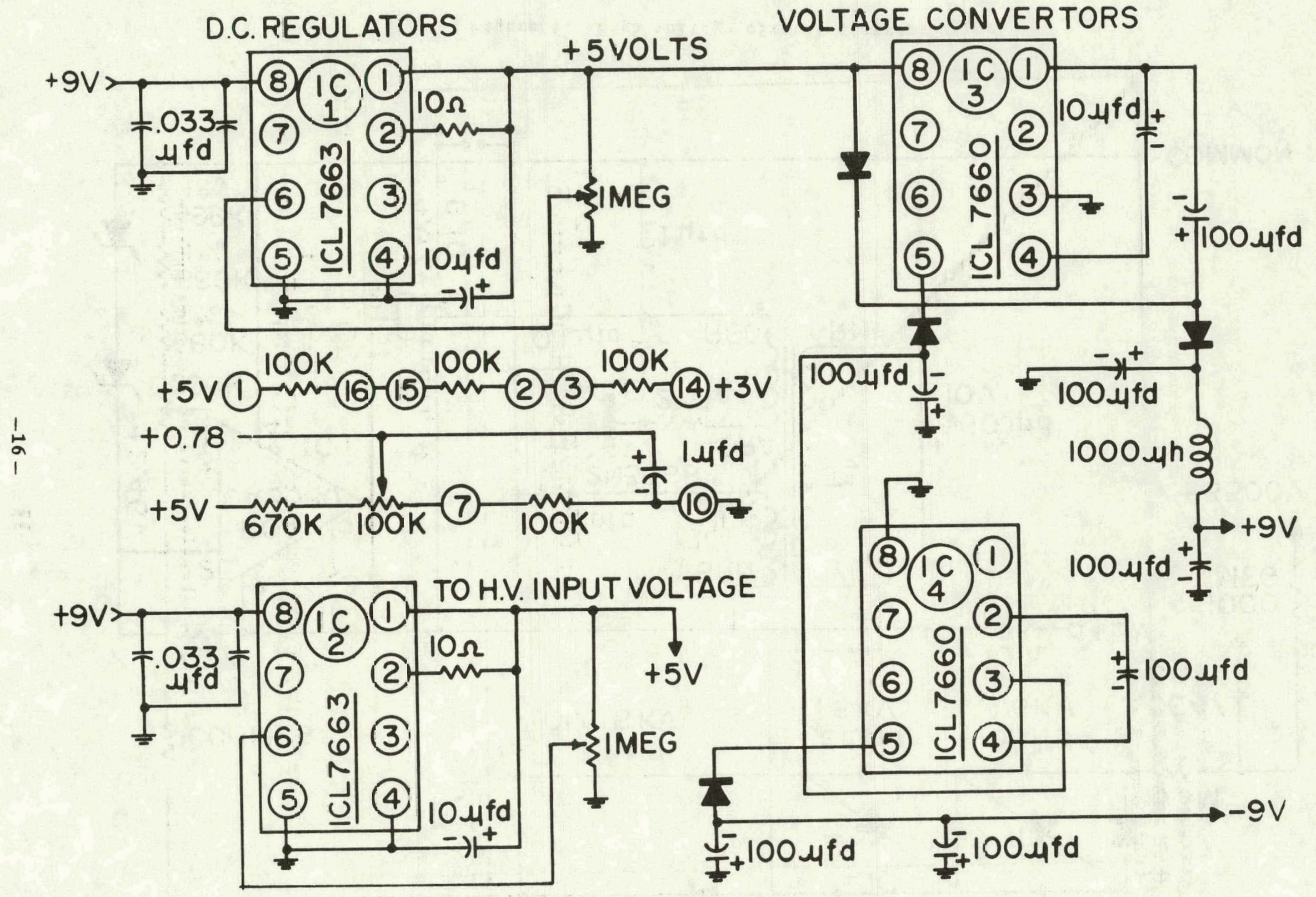

Figure 7. Low voltage circuit diagram. 


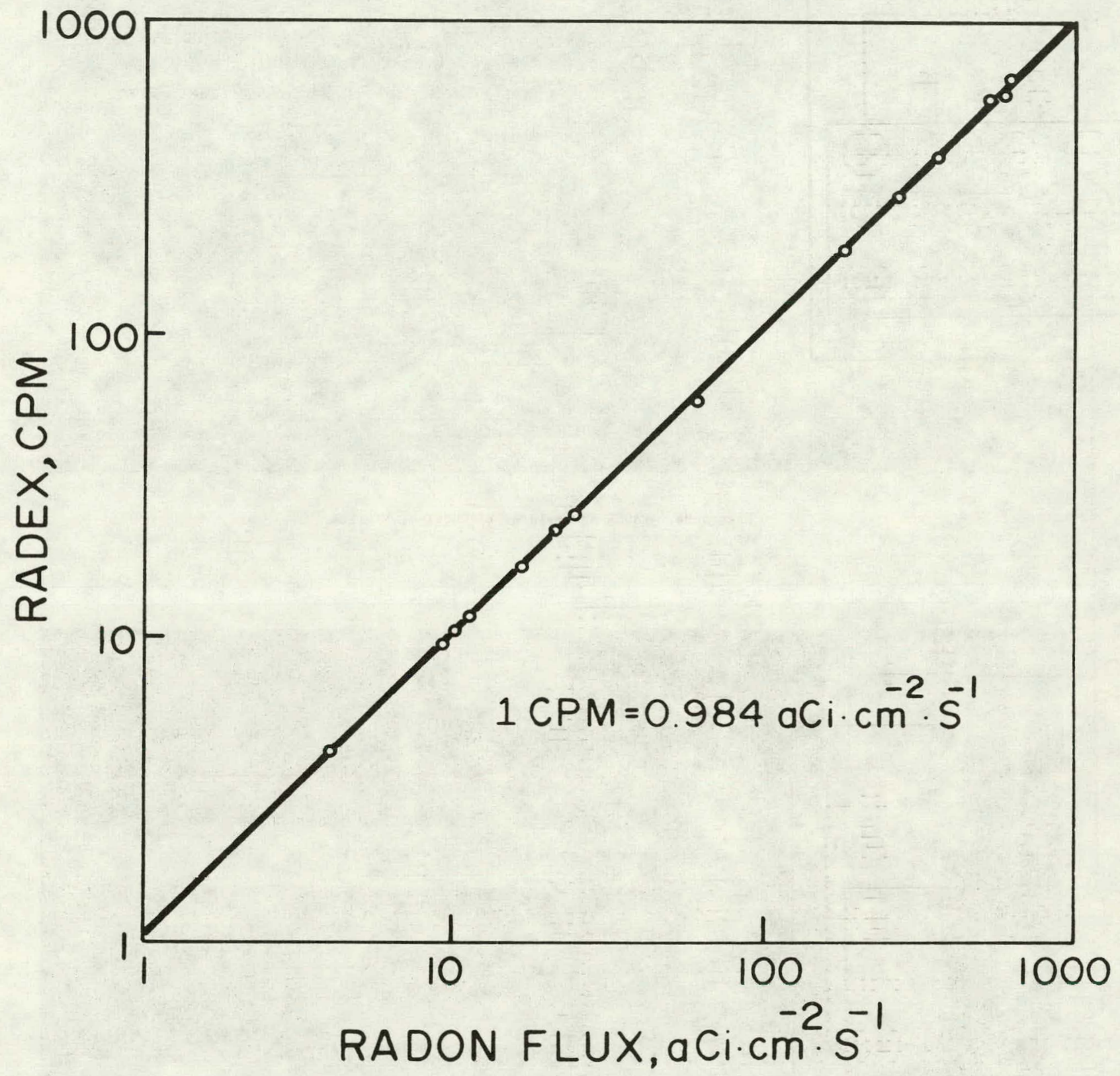

Figure 8. Calibration curve of the RADEX monitor. 


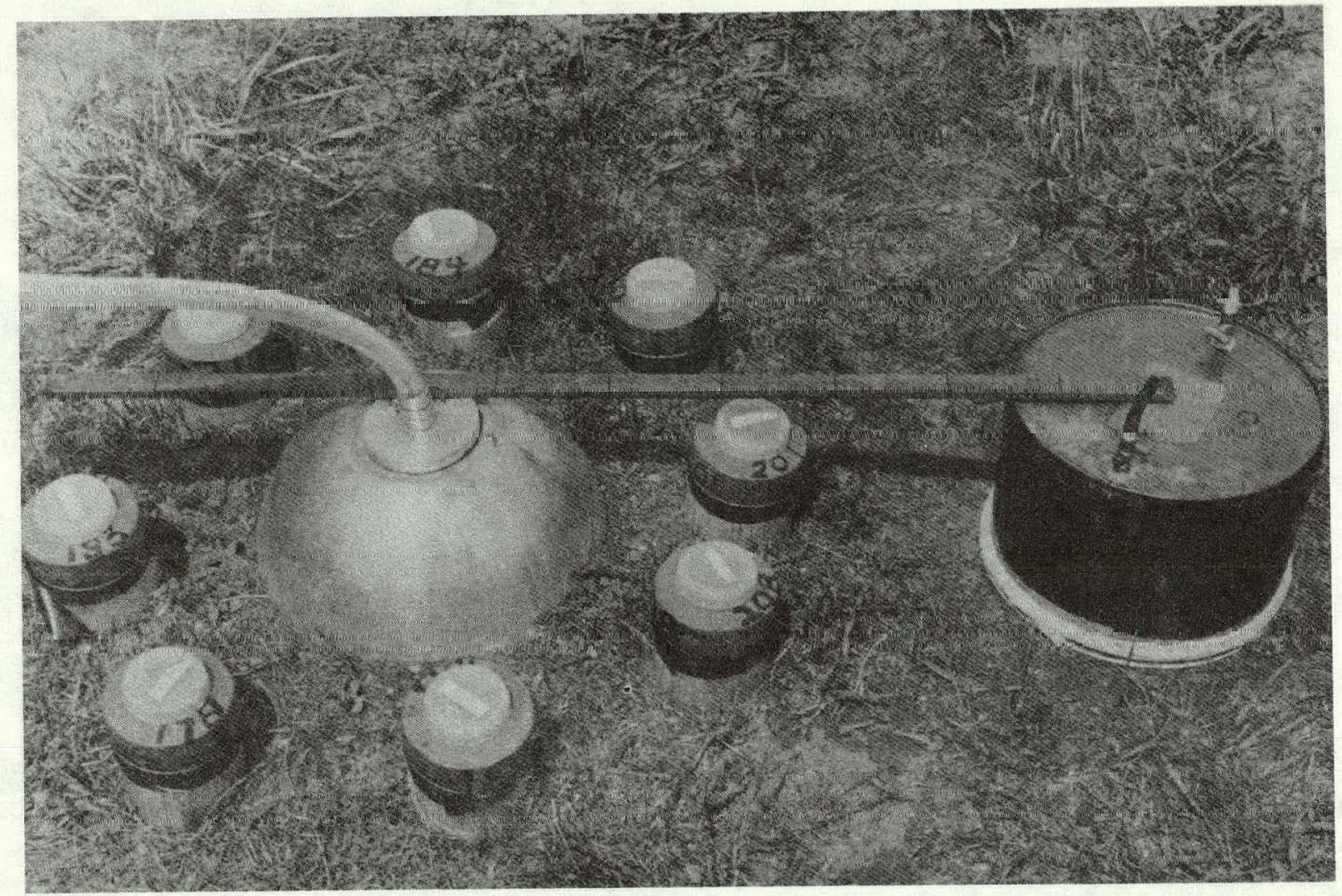

Figure 9a. RADEX accumulator at Chester, NJ site.

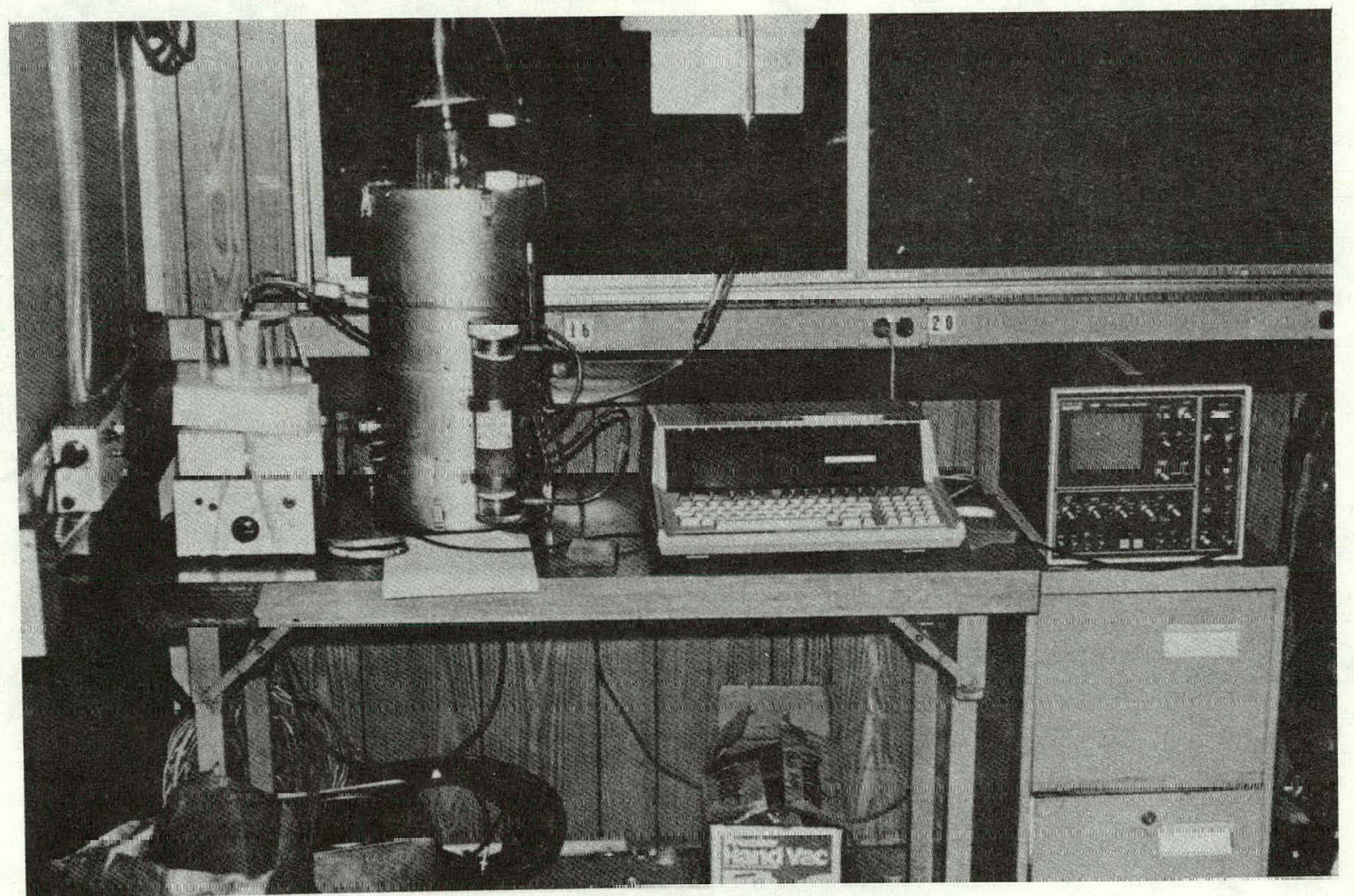

Figure 9b, RADEX monitor in trailer at Chester, NJ site. 


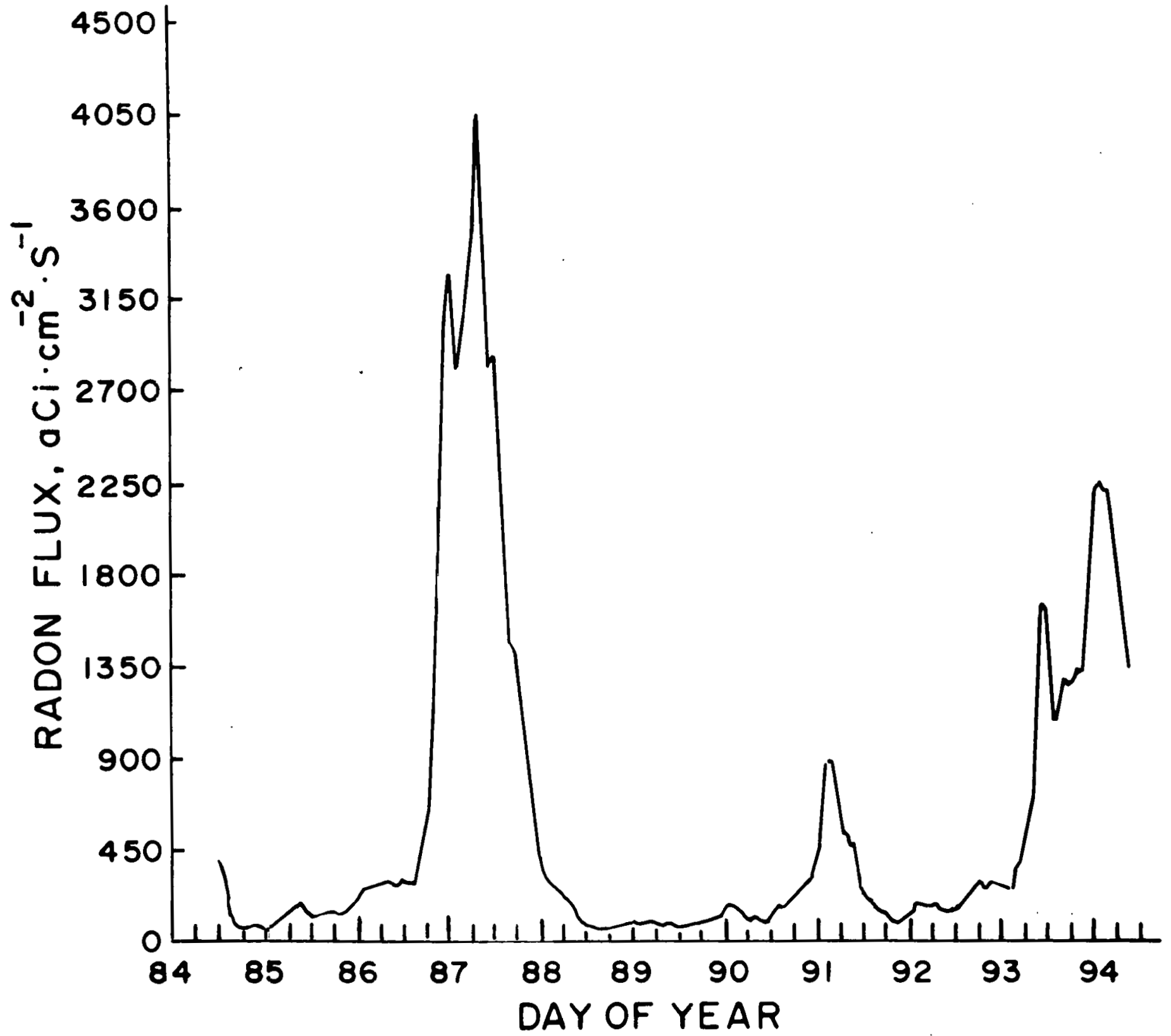

Figare 10. Ten day plot of the RADEX monitor at Chester, NJ site. 
